Volume 4 Nomor 2, Agustus 2019, halaman 98-113

\title{
PERBANDINGAN KEMAMPUAN PEMECAHAN MASALAH MATEMATIS SISWA ANTARA PEMBELAJARAN YANG MENGGUNAKAN MODEL TEAM ASSISTED INDIVIDUALIZATION DENGAN MODEL DIRECT INSTRUCTION
}

\author{
THE COMPARISON OF MATHEMATICAL PROBLEM SOLVING ABILITY OF \\ STUDENTS BETWEEN LEARNING USING THE TEAM ASSISTED \\ NDIVIDUALIZATION MODEL WITH DIRECT INSTRUCTION MODEL
}

\author{
Nanang Irwandi ${ }^{1}$, Muh. Aripin Nurmantoro ${ }^{2}$ \\ ${ }^{1}$ Universitas Wiralodra, Jl. Ir. H. Djuanda KM. 03 Singaraja - Indramayu, irwandi647@ gmail.com \\ ${ }^{2}$ STKIP Al-Amin Indramayu, Jl. PU Kemped Wirakanan - Kandanghaur, \\ aripin.nurmantoro@gmail.com
}

\begin{abstract}
ABSTRAK
Penelitian ini dilakukan dengan tujuan untuk mengetahui kemampuan pemecahan masalah matematis siswa yang menggunakan model pembelajaran Team Asissted Individualization; kemampuan pemecahan masalah matematis siswa yang menggunakan model pembelajaran Direct Instruction; dan untuk mengetahui kemampuan pemecahan masalah matematis siswa yang lebih baik antara yang menggunakan model pembelajaran Team Asissted Individualization dengan Direct Instruction. Penelitian ini dilakukan dengan metode eksperimen, dengan menggunakan teknik cluster random sampling, dan setelah dilakukan pengundian, Kelas VIII B dan Kelas VIII D terpilih sebagai sampel. Kelas VIII D digunakan sebagai kelas eksperimen I yang pembelajarannya menggunakan model pembelajaran Team Asissted Individualization dan kelas VIII D digunakan sebagai kelas eksperimen II yang pembelajarannya menggunakan model pembelajaran Direct Instruction. Sedangkan teknik analisis data yang digunakan dalam penelitian ini adalah uji-t. Berdasarkan hasil analisis data yang telah dilakukan maka dapat disimpulkan bahwa kemampuan pemecahan masalah matematis siswa yang menggunakan model pembelajaran Team Asissted Individualization lebih baik daripada Direct Instruction.
\end{abstract}

Kata Kunci : Kemampuan Pemecahan Masalah Matematis, Team Asissted Individualization, Direct Instruction.

\footnotetext{
ABSTRACT

This purpose of this study are to find out to determine the mathematical problem solving abilities of students using the Team Asissted Individualization learning models; mathematical problem solving abilities of students who use the Direct Instruction learning models; and to find out the better mathematical problem solving abilities of students who use the Team Asissted Individualization learning models with Direct Instruction. This research was conducted by experimental method, using cluster random sampling technique, and after drawing, Class VIII B and Class VIII D were selected as samples. Class VIII D was used as the experimental class I, where the learning used the Learning Team Team Individualization model and class VIII D was used as the experimental class II, where the learning used the Direct Instruction learning model. While the data analysis technique used in this study is the t-test. Based on the results of data analysis that has been done, it can be concluded that the mathematical problem solving abilities of students who use The Team Asissted Individualization learning models are better than Direct Instruction Model.

Keyword(s) : Mathematical Problem Solving Abilities, Team Asissted Individualization Model, Direct Instruction Model.
} 
How to Cite: Irwandi, N \& Nurmantoro, M. A. (2019). Perbandingan Kemampuan Pemecahan Masalah Matematis Siswa Antara Yang Pembelajarannya Menggunakan Model Team Assisted Individualization Dengan Model Direct Instruction. Mathline: Jurnal Matematika dan Pendidikan Matematika, Vol.4, No.2, 98-113.

\section{PENDAHULUAN}

Dalam Pasal 3 Undang-undang Republik Indonesia Nomor 20 Tahun 2003 tentang Sistem Pendidikan Nasional disebutkan bahwa Pendidikan Nasional bertujuan untuk berkembangnya potensi peserta didik agar menjadi manusia yang beriman dan bertaqwa kepada Tuhan Yang Maha Esa, berakhlak mulia, sehat, berilmu, cakap, kreatif, mandiri dan menjadi warga Negara yang demokratis dan bertanggung jawab. Di era globalisasi sekarang ini dibutuhkan adanya sumber daya manusia yang berkualitas dan berdaya saing tinggi. Hal ini karena jumlah penduduk yang semakin besar dan persaingan semakin ketat. Oleh karena itu, dunia pendidikan dituntut untuk dapat meningkatkan mutu pendidikan dan dapat menciptakan sumber daya manusia yang berkualitas dan berprestasi tinggi. Upaya peningkatan kualitas pendidikan secara nasional merupakan salah satu agenda yang sedang dilaksanakan oleh pemerintah, upaya ini diarahkan agar setiap lembaga pendidikan selalu berupaya untuk memberikan jaminan kualitas kepada pihak-pihak yang berkepentingan atau masyarakat yakni suatu jaminan bahwa penyelenggaraan pendidikan di sekolahsekolah sesuai dengan apa yang seharusnya terjadi dan sesuai pula dengan harapan mereka, sehingga mutu pendidikan secara nasional akan terus meningkat.

Pembelajaran matematika hendaknya lebih bervariasi baik metode maupun strateginya guna mengoptimalkan potensi siswa, hal tersebut memicu agar guru dapat berupaya mengatur atau berupaya memberdayakan berbagai variabel pembelajaran sehingga dapat tercapai tujuan yang direncanakan. Karena itu pemilihan metode, strategi, dan pendekatan dalam mendesain model pembelajaran guna tercapainya iklim pembelajaran yang aktif dan bermakna adalah tuntutan yang harus dipenuhi. Sehingga kemampuan pemecahan masalah dalam pembelajaran matematika sangat penting untuk dikembangkan. Wena (2011) kemampuan Pemecahan masalah dipandang sebagai suatu proses untuk menemukan kombinasi dari sejumlah aturan yang dapat diterapkan dalam upaya mengatasi situasi yang baru. Sedangkan Wijaya (2012) menyatakan bahwa kemampuan pemecahan masalah dipandang sebagai suatu keterampilan tingkat tinggi (high-level-skill) yang merupakan jantung dari matematika. 
Perbandingan Kemampuan Pemecahan Masalah Matematis Siswa Antara Pembelajaran yang Menggunakan Model Team Assisted Individualization dengan Model Direct Instruction

Slameto (2010) menyatakan bahwa "belajar adalah suatu proses usaha yang dilakukan seseorang untuk memperoleh suatu perubahan tingkah laku yang baru secara keseluruhan, sebagai hasil pengalamannya dalam interaksi dengan lingkungannya". Dinamika yang terjadi selama pembelajaran berlangsung, diantaranya adanya sebagian siswa hanya pasif, tidak mau berpikir dan menerima begitu saja materi pelajaran yang disampaikan oleh guru. Bahkan ada kesan siswa hanya menunggu penjelasan dari guru dalam menyelesaikan soal-soal yang dihadapi, tanpa mencoba menghubungkan dan menerapkan konsep yang sudah disampaikan oleh guru sebelumnya. Sehingga dibutuhkan salah satu alternatif yang dapat digunakan untuk meningkatkan kemampuan pemecahan masalah matematis siswa dengan cara penerapan metode pembelajaran kooperatif. Fathurrohman (2015) berpendapat bahwa dalam pembelajaran kooperatif, siswa dituntut untuk lebih aktif dan bekerjasama dalam pembelajaran supaya siswa mampu memecahkan masalah matematis dengan baik, model pembelajaran kooperatif merupakan model pembelajaran yang mengutamakan kerja sama di antara siswa untuk mencapai tujuan pembelajaran. Suprijono (2015) menyatakan bahwa model pembelajaran ialah pola yang digunakan sebagai pedoman dalam merencanakan pembelajaran di kelas maupun tutorial. Dimana hal tersebut juga sejalan dengan pendapat Fathurrohman (2015) yang menyatakan bahwa model pembelajaran sebagai suatu perencanaan atau suatu pola yang digunakan sebagai pedoman dalam melaksanakan pembelajaran di kelas atau pembelajaran dalam tutorial dan untuk menentukan perangkat-perangkat pembelajaran. Sehingga perencanaan pembelajaran sangat penting supaya proses pembelajaran di kelas sesuai dengan perangkat pembelajaran yang ada. Selain itu, Sutawidjaja \& Dahlan (2011) menyatakan, model pembelajaran langsung adalah model mengajar yang dirancang khusus untuk menunjang proses belajar yang berkaitan dengan pengetahuan deklaratif dan pengetahuan prosedural yang terstruktur dengan baik yang dapat diajarkan dengan pola kegiatan bertahap.

Model pembelajaran kooperatif memiliki beberapa tipe, salah satunya adalah model pembelajaran Team Assisted Individulaization. Lestari \& Yudhanegara, (2015) menyatakan bahwa pembelajaran Team Assisted Individulaization adalah satu tipe dari model pembelajaran kooperatif yang mengkombinasikan pembelajaran kooperatif dan pembelajaran Individual. Sedangkan, Daryanto (2013) berpendapat bahwa model pembelajaran Team Assisted Individualization ini dirancang untuk mengatasi kesulitan belajar siswa, adapun ciri khas pada tipe ini adalah setiap peserta didik secara individual belajar materi pembelajaran yang sudah dipersiapkan oleh guru, dan hasil belajar individual dibawa ke kelompok-kelompok untuk didiskusikan dan saling dibahas oleh 
anggota kelompok dan semua anggota kelompok. Dalam penelitian ini, model pembelajaran Team Assisted Individualization adalah model pembelajaran dimana guru membentuk kelompok yang heterogen dan siswa yang pandai dapat membantu siswa yang lemah, setiap peserta didik secara individual belajar materi pembelajaran yang sudah dipersiapkan oleh guru. Hasil belajar individual dibawa ke kelompok-kelompok untuk didiskusikan dan saling dibahas oleh anggota kelompok.

Penelitian yang dilakukan oleh Good dan Brophy (Muijs \& Reynolds, 2008) yang dikutip Trisnawati (2018) menyatakan bahwa Direct Instruction merupakan metode terbaik untuk mengajarkan tentang aturan, prosedur, dan keterampilan dasar khususnya untuk murid-murid belia. Menurut Huitt, Monetti, dan Hummel yang dikutip Sari (2013) menyatakan bahwa "Direct Instruction merupakan model pembelajaran yang diarahkan sebagai model pembelajaran yang bermutu tinggi dan terpilih untuk mengembangkan keterampilan dan pengetahuan siswa yang lebih mendalam melalui manajemen waktu yang efisien serta keterampilan mengajar guru yang baik”. Berdasarkan beberapa deskripsi tersebut, dapat disimpulkan bahwa Direct Instruction adalah model pembelajaran yang dirancang khusus yang bertujuan membantu siswa untuk menunjang proses belajar yang berkaitan dengan pengetahuan deklaratif dan pengetahuan prosedural yang dapat diajarkan secara bertahap selangkah demi selangkah melalui manajemen waktu yang efisien serta keterampilan mengajar guru yang baik. Dalam hal ini model pembelajaran langsung adalah model pembelajaran yang dirancang khusus yang bertujuan untuk membantu siswa untuk menunjang proses belajar yang berkaitan dengan pengetahuan deklaratif dan pengetahuan prosedural yang dapat diajarkan secara bertahap selangkah demi selangkah melalui manajemen waktu yang efisien serta keterampilan mengajar guru yang baik.

Hartini (2017) menyatakan bahwa setiap siswa yang telah memiliki kemampuan pemecahan masalah yang berkaitan dengan materi pembelajaran matematika akan sangat membantu proses pemahaman atau pembentukan pengetahuan baru bagi siswa. Selain itu, Kemampuan pemecahan masalah bertujuan untuk mengurangi tingkat kecemasan matematika oleh kerena itu perlu adanya suatu upaya pembelajaran yang mengarahkan siswa pada kemampuan pemecahan masalah tersebut (Setiani, 2016). Dalam proses pemecahan masalah matematika tentunya terdapat langkah-langkah yang harus ditempuh untuk menemukan solusi dari persoalan yang ada (Lestari, Andinny \& Mailizar, 2019). Lebih dari itu, kemampuan siswa untuk memecahkan masalah matematis perlu terus dilatih sehingga ia dapat memecahkan masalah yang ia hadapi (Effendi, 2012). Berdasarkan beberapa deskripsi di atas dapat disimpulkan bahwa kemampuan pemecahan 
Perbandingan Kemampuan Pemecahan Masalah Matematis Siswa Antara Pembelajaran yang Menggunakan Model Team Assisted Individualization dengan Model Direct Instruction

masalah matematis adalah keterampilan matematika tingkat tinggi yang dimiliki siswa dalam menyelesaikan masalah-masalah yang tidak rutin, yang dapat diterapkan dalam upaya mengatasi situasi yang baru. Dalam hal ini, dilakukan identifikasi, perumusan masalah, penerapan strategi, dan menjelasakan dan menginterpretasikan. Sedangkan kemampuan pemecahan masalah yang dimaksud dalam penelitian ini adalah kemampuan pemecahan masalah yang dimiliki siswa setelah menerima pembelajaran sistem persamaan linier dua variabel.

Proses pemecahan masalah matematik berbeda dengan proses menyelesaikan soal matematika, jadi apabila suatu soal matematika dapat segera ditemukan cara menyelesaikannya, maka soal tersebut tergolong pada soal rutin dan bukan merupakan suatu masalah (Hidayat \& Sariningsih, 2018). Disisi lain, salah satu masalah dalam pembelajaran matematika adalah rendahnya tingkat kemampuan peserta didik dalam menyelesaikan soal yang berkaitan dengan kehidupan sehari-hari (Lestari, Andinny \& Mailizar, 2019). Menyadari bahwa masalah yang berkaitan dengan penelitian sangat kompleks, maka pembatasan masalah dalam penelitian ini sangat dibutuhkan agar penulis lebih fokus dan tidak melenceng dari permasalahan. Adapun masalah utama dalam penelitian ini yaitu perbandingan kemampuan pemecahan masalah matematis siswa antara yang pembelajarannya menggunakan model pembelajaran Team Assisted Individulaization dengan model pembelajaran Direct Intruction. Adapun ruang lingkup dalam penelitian ini dibatasi hanya pada pokok bahasan persamaan linear dua variabel. Sedangkan tujuan penelitian ini diantaranya untuk mengetahui gambaran kemampuan pemecahan masalah matematis siswa yang menggunakan model pembelajaran Team Assisted Individulaization; gambaran kemampuan pemecahan masalah matematis siswa yang menggunakan model Pembelajaran Direct Intruction; dan untuk mengetahui apakah kemampuan pemecahan masalah matematis siswa yang menggunakan model pembelajaran Team Assisted lebih baik dengan yang menggunakan model pembelajaran Direct Intruction.

\section{METODE PENELITIAN}

Penelitian eksperimen ini dilakukan di MTs Al Wasliyah Kecamatan Anjatan Kabupaten Indramayu Provinsi Jawa Barat, yang dilaksanakan pada semester ganjil Tahun Pelajaran 2018/2019. Populasi dalam penelitian ini adalah seluruh kemampuan pemecahan masalah matematis siswa materi sistem persamaan linier dua variabel kelas VIII. Sedangkan teknik pengambilan sampel dalam penelitian ini menggunakan Cluster Random Sampling dan akan dipilih 2 (dua) kelas sebagai sampel, adapun pemilihan sampel 
dilakukan dengan cara diundi dan setelah dilakukan pengundian terpilih kelas VIII B dan kelas VIII D sebagai sampel, kemudian hasil diskusi dengan pihak sekolah ditetapkan kelas VIII B sebagai kelas eksperimen I yang pembelajarannya menggunakan tipe Team Asissted Individualization dan kelas VIII D sebagai kelas eksperimen II yang pembelajarannya menggunakan Direct Intructions.

Populasi dalam penelitian ini adalah seluruh kemampuan pemecahan masalah matematis siswa materi sistem persamaan linier dua variabel kelas VIII Tahun Pelajaran 2018/2019 yang terbagi menjadi dua kelas, adapun data siswa sebagai berikut:

Tabel 1. Data Siswa

\begin{tabular}{cc}
\hline Kelas & Jumlah Siswa \\
\hline VIII A & 20 Orang \\
VIII B & 21 Orang \\
VIII C & 21 Orang \\
VIII D & 22 Orang \\
\hline
\end{tabular}

Pemilihan sampel dilakukan dengan cara diundi sehingga tiap sampel mempunyai peluang yang sama, setelah dilakukan pengundian terpilih kelas VIII B dan VIII D sebagai sampel. Disamping itu, berdasarkan hasil diskusi dengan pihak sekolah ditetapkan kelas VIII B yang selanjutnya digunakan untuk kelas eksperimen I yaitu yang pembelajarannya menggunakan tipe Team Asissted Individualization dan kelas VIII D digunakan untuk kelas eksperimen II yang pembelajarannya menggunakan Direct Intructions.

Metode yang digunakan dalam penelitian ini adalah metode penelitian eksperimen. Menurut Sugiyono (2015), "Metode penelitian eksperimen dapat diartikan sebagai metode penelitian yang digunakan untuk mencari pengaruh perlakuan tertentu terhadap yang lain dalam kondisi yang terkendalikan”. Selanjutnya kedua kelas sampel masingmasing diberi perlakuan, kelas eksperimen I diberi perlakuan dengan menggunakan metode pembelajaran kooperatif tipe Team Asissted Individualization, sedangkan kelas eksperimen II diberi perlakuan dengan menggunakan metode pembelajaran kooperatif tipe Direct Intructions. Adapun desain penelitian yang dikutip dari Lestari \& Yudhanegara (2015) sebagai berikut:

$$
\begin{aligned}
& \wedge: T_{1}() \\
& \wedge: T_{2}()
\end{aligned}
$$

\section{Gambar 1. Desain Penelitian}

Keterangan :

A : Pengambilan sampel secara acak (random). 
Perbandingan Kemampuan Pemecahan Masalah Matematis Siswa Antara Pembelajaran yang Menggunakan Model Team Assisted Individualization dengan Model Direct Instruction

$\mathrm{T}_{1}$ : Perlakuan untuk kelas eksperimen I (menggunakan Team Asissted Individualization)

$\mathrm{T}_{2}$ : Perlakuan untuk kelas eksperimen II (menggunakan Direct Intructions.)

$\mathrm{O}:$ Hasil Tes akhir

Sugiyono (2015) menyatakan bahwa pada prinsipnya meneliti adalah melakukan pengukuran, maka harus ada alat ukur yang baik. Alat ukur dalam penelitian dinamakan instrumen penelitian. Instrumen dalam penelitian ini yaitu instrumen untuk mengukur kemampuan pemecahan masalah matematis siswa materi sistem persamaan linier dua variabel. Tes kemampuan pemecahan masalah matematis siswa materi sistem persamaan linier dua variabel dengan tipe soal berbentuk pemecahan masalah dalam kehidupan sehari-hari. Banyaknya soal tes yang diberikan sebanyak 5 butir soal. Tiap indikator dapat dibuat alat ukurnya berupa tes uraian dan jawaban masing-masing diberi skor. Interpretasi skor yang akan digunakan berdasarkan tingkat rubrik kemampuan pemecahan masalah. Oleh karena itu kemampuan pemecahan masalah matematis siswa materi sistem persamaan linier dua variabel dengan tipe soal berbentuk pemecahan masalah dalam kehidupan seharri hari secara operasional diwakili oleh skor hasil tes uraian. Adapun instrumen yang digunakan untuk mengukur kemampuan pemecahan masalah matematis siswa materi sistem persamaan linier dua variabel adalah dalam bentuk tes uraian dengan indikator kemampuan pemecahan masalah matematis dalam penelitian ini dapat dilihat pada tabel berikut.

Tabel 2. Indikator Kemampuan Pemecahan Masalah Matematis Siswa

\begin{tabular}{lcl}
\hline Indikator & Skor & Tahapan Penyelesaian \\
\hline \multirow{2}{*}{ Memahami Masalah } & 1 & Tidak ada jawaban \\
& 2 & Sebagian masalah disalah tafsirkan \\
& 0 & Tidak ada data yang terkumpul \\
Merencanakan & 1 & Sebagian data terkumpul \\
Pemecahan Masalah & 2 & Semua data terkumpul \\
& 0 & Tidak ada analisa atau perhitungan \\
Melaksanakan Rencana & 1 & Ada analisa atau perhitungan sebagian \\
Pemecahan Masalah & 2 & Ada analisa atau perhitungan secara lengkap \\
& 0 & Jawaban salah \\
Mengecek Kembali & 1 & Sebagian jawaban benar \\
& 2 & Seluruh penyelesaian \\
\hline
\end{tabular}


Untuk memenuhi validitas isi, maka penyusunan soal tes berdasarkan indikator, adapun materi yang diambil yaitu sistem persamaan linear dua variabel, dengan kompetensi dasar dan indikator sebagai berikut:

\section{1) Kompetensi Dasar}

a) Mendeskripsikan konsep sistem persamaan linier dua variabel dan mampu menerapkan berbagai strategi yang efektif dalam menentukan himpunan penyelesaiannya serta memeriksa kebenaran jawabannya dalam pemecahan masalah matematika.

b) Menggunakan sistem persamaan linier dua variabel untuk menyajikan masalah kontekstual dan menjelaskan makna tiap besaran secara lisan maupun tulisan.

c) Membuat model matematika berupa sistem persamaan linier dua variabel dari situasi nyata dan matematika, serta menentukan jawab dan menganalisis model sekaligus jawabnya.

\section{2) Indikator}

a) Mengidentifikasi unsur-unsur yang diketahui, ditanyakan, dan kecukupan unsur yang diperlukan.

b) Merumuskan masalah matematis atau menyusun model matematis.

c) Menerapkan strategi untuk menyelesaikan masalah.

d) Menjelaskan dan menginterpretasikan hasil penyelesaian masalah

Selanjutnya untuk menguji valid atau tidaknya instrumen secara empiris, penulis melakukan uji coba instrumen tersebut pada sasaran dalam penelitian. Berdasarkan hasil uji instrumen kemampuan pemecahan masalah matematis siswa materi sistem persamaan linier dua variabel, dengan kriteria jika $t_{\text {hitung }}>t_{k r i t i s}$ maka butir soal dinyatakan valid adapun hasil pengujian sebagai berikut.

Tabel 3. Validitas Hasil Uji Coba Instrumen

\begin{tabular}{ccccc}
\hline Butir Soal & Nilai $r_{X Y}$ & $\boldsymbol{t}_{\text {hitung }}$ & $\boldsymbol{t}_{(\mathbf{0}, \mathbf{0 5} ; \mathbf{1 1})}$ & Keterangan \\
\hline 1 & 0,7587 & 4,9419 & 1,734 & Valid \\
2 & 0,7652 & 5,0423 & 1,734 & Valid \\
3 & 0,6822 & 3,9583 & 1,734 & Valid \\
4 & 0,7631 & 5,0095 & 1,734 & Valid \\
5 & 0,5710 & 2,9512 & 1,734 & Valid \\
\hline
\end{tabular}


Perbandingan Kemampuan Pemecahan Masalah Matematis Siswa Antara Pembelajaran yang Menggunakan Model Team Assisted Individualization dengan Model Direct Instruction

Berdasarkan keterangan di atas, instrumen kemampuan pemecahan masalah matematis siswa materi sistem persamaan linier dua variabel yang terdiri dari 5 soal uraian semuanya dikatakan valid. Karena semua soal dinyatakan valid, maka semua instrumen kemampuan pemecahan masalah matematis siswa materi sistem persamaan linier dua variabel dapat digunakan.

Disamping itu, pengujian reliabilitas instrumen dalam penelitian ini dilakukan dengan cara Internal Consistency, yakni dilakukan dengan cara mencobakan instrumen sekali saja, dan berdasarkan data dari hasil uji coba yang dilakukan diketahui bahwa $r_{11}=$ 0,743 dan $t_{\text {hitung }}=4,71$ serta $t_{\text {kritis }}=1,734$. Karena thitung $>t_{\text {kritis, }}$, sehingga dapat dikategorikan bahwa instrumen kemampuan pemecahan masalah matematis dinyatakan reliable dan termasuk ke dalam kategori tinggi.

\section{HASIL DAN PEMBAHASAN}

Hasil perhitungan dan pengujian yang dilakukan dengan bantuan komputer melalui program Microsoft Excel, serta analisis dan intepretasinya sebagai berikut.

Tabel 4. Deskripsi Data Penelitian

\begin{tabular}{ccccccc}
\hline \multicolumn{1}{c}{ Kelas } & $\begin{array}{c}\text { Jumlah } \\
\text { siswa }\end{array}$ & $\begin{array}{c}\text { Skor } \\
\text { Tertinggi }\end{array}$ & $\begin{array}{c}\text { Skor } \\
\text { Terendah }\end{array}$ & $\begin{array}{c}\text { Rata- } \\
\text { rata }\end{array}$ & Varians & $\begin{array}{c}\text { Standar } \\
\text { Deviasi }\end{array}$ \\
\hline Eksperimen I & 21 & 37 & 24 & 29,853 & 12,129 & 3,483 \\
Eksperimen II & 22 & 31 & 17 & 23,045 & 14,903 & 3,860 \\
\hline
\end{tabular}

Disamping itu, histogram hasil tes kemampuan pemecahan masalah matematis kelas eksperimen I yang menggunakan model pembelajaran Team Asissted Individualization sebagai berikut.

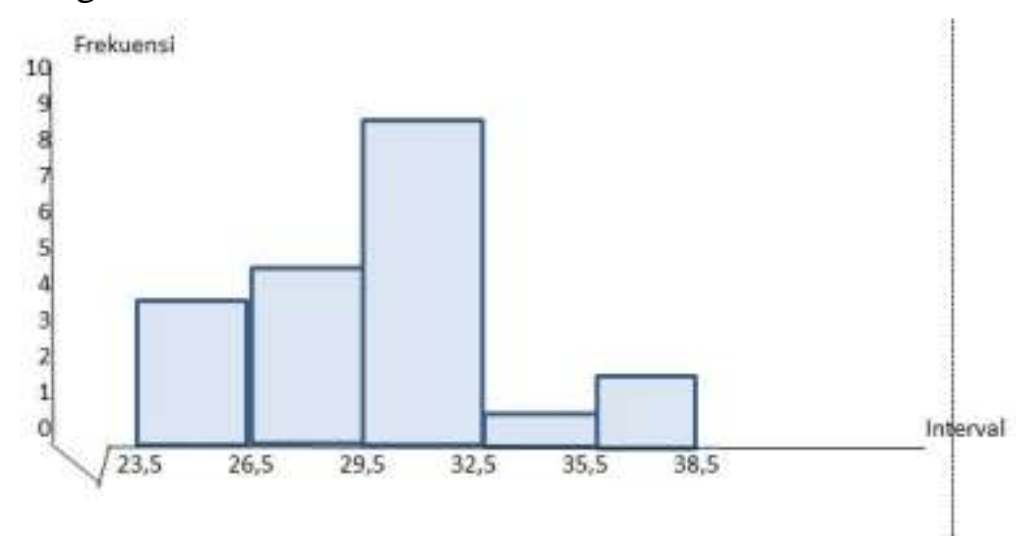

Gambar 2. Histogram Hasil Tes Akhir Kelas Eksperimen I 
Sedangkan, histogram hasil tes kemampuan pemecahan masalah matematis kelas eksperimen II yang menggunakan model pembelajaran Direct Instruction sebagai berikut.

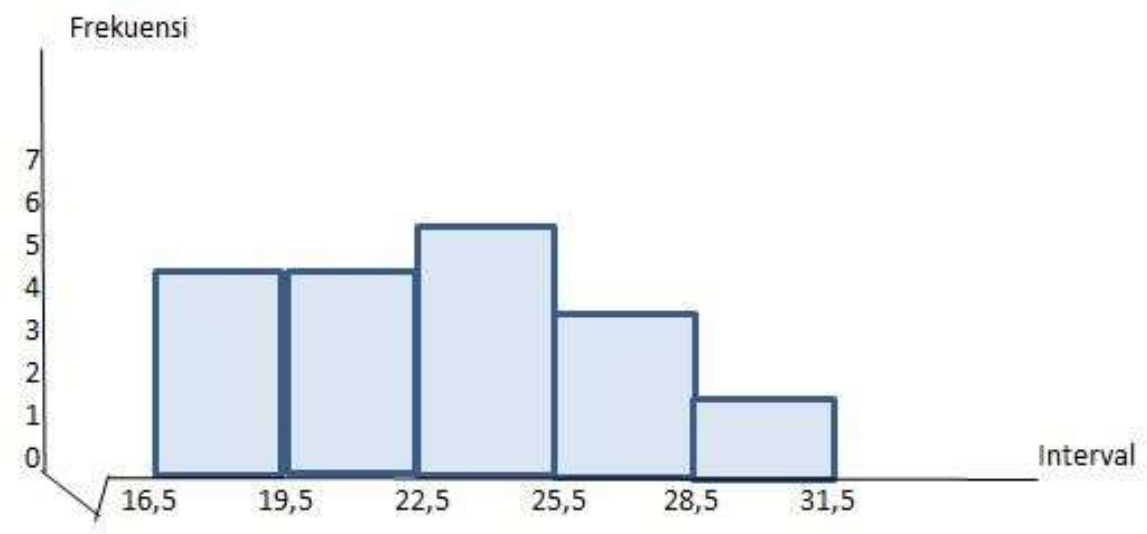

\section{Gambar 3. Histogram Hasil Tes Akhir Kelas Eksperimen II}

Berdasarkan tabel dan histogram di atas menunjukkan bahwa skor rata-rata kemampuan pemecahan masalah matematis kelas eksperimen I yang menggunakan model pembelajaran Team Asissted Individualization adalah 29,853, varians 12,129, dan simpangan baku 3,483. Sedangkan skor rata-rata kemampuan pemecahan masalah matematis kelas eksperimen II yang menggunakan model pembelajaran Direct Instruction adalah 23, 045, varians 14,903, dan simpangan baku 3,860. Berdasarkan deskripsi tersebut menunjukkan bahwa kelas eksperimen I memiliki pemusatan data pada 29,853 dan penyebaran data dengan variasi sebesar 12,129 dan simpangan baku sebesar 3,483. Sedangkan kelas eksperimen II memiliki pemusatan data pada 23,045 dan penyebaran data dengan variasi sebesar 14,903 dan simpangan baku sebesar 3,860.

Dari data tersebut diperoleh perbedaan antara kelas eksperimen I yang menggunakan model pembelajaran Team Asissted Individualization dan kelas eksperimen II yang menggunakan model pembelajaran Direct Instruction. Dengan kata lain dapat dikatakan bahwa kelas eksperimen I lebih menyebar dan bervariasi dibandingkan dengan data kelas eksperimen II. Namun perbedaan tersebut belum menentukan kelas mana yang memiliki kemampuan pemecahan masalah matematis siswa yang lebih baik, dengan demikian diperlukan uji hipotesis terlebih dahulu.

\section{Uji Persyaratan Analisis Data}

Setelah diperoleh rata-rata dan standar deviasi, peneliti selanjutnya melakukan uji normalitas dan homogenitas varians kelas ekperimen I dan kelas eksperimen II.s

\section{a. Uji Normalitas}


108 Perbandingan Kemampuan Pemecahan Masalah Matematis Siswa Antara Pembelajaran yang Menggunakan Model Team Assisted Individualization dengan Model Direct Instruction

Uji normalitas dilakukan untuk mengetahui normal atau tidaknya data yang diperoleh, adapun hasil uji normalitas dalam penelitian ini sebagai berikut.

\section{Tabel 5. Hasil Perhitungan Uji Normalitas}

\begin{tabular}{ccc}
\hline Kelas & $\chi_{\text {obs }}^{2}$ & $\chi_{\text {kritis }}^{2}$ \\
\hline Eksperimen I & 5,60 & \\
Eksperimen II & 5,74 & 5,99 \\
\hline
\end{tabular}

Berdasarkan data di atas menunjukkan bahwa pada kelas eksperimen I diperoleh $\chi_{o b s}^{2}=5,609$ dan $\chi_{\text {kritis }}^{2}=5,99$ sedangkan kelas eksperimen II $\chi_{o b s}^{2}=5,74$ dan $\chi_{\text {kritis }}^{2}=5,99$, dengan taraf signifikan $\alpha=0,05$ dan derajat kebebasan $\mathrm{db}=k-$ $1=5-1=4$. Karena $\chi_{o b s}^{2}<\chi_{\text {kritis }}^{2}$, maka dapat disimpulkan bahwa kedua kelompok berdistribusi normal.

\section{b. Uji Homogenitas}

Setelah data tes kemampuan pemecahan masalah matematis siswa kelas eksperimen I dan kelas eksperimen II berdistribusi normal, selanjutnya dilakukan uji homogenitas dua varians. Adapun hasil perhitungan diperoleh data sebagai berikut.

Tabel 6. Hasil Pengujian Homogenitas Dua Varian

\begin{tabular}{ccccc}
\hline Kelas & $\boldsymbol{N}$ & Varians & $\boldsymbol{F}_{\text {obs }}$ & $\boldsymbol{F}_{\text {kritis }}$ \\
\hline Eksperimen I & 21 & 12,129 & & \\
Eksperimen II & 22 & 14,903 & 0,814 & 2,096 \\
\hline
\end{tabular}

Dari data uji homogentas dua varians dengan taraf signifikan $\alpha=0,05$ dan $\mathrm{db}_{1}=21$ dan $\mathrm{db}_{2}=22$, diperoleh $F_{\text {obs }}=0,814$ dan $F_{\text {kritis }}=2,096$. Berdasarkan kriteria uji homogenitas dapat disimpulkan bahwa $F_{o b s}<F_{\text {kritis }}$, maka data tes kemampuan pemecahan masalah matematis siswa kelas eksperimen I dan kelas eksperimen II bersifat homogen.

\section{c. Uji-t (Uji Kesamaan Dua Rata-rata)}

Setelah uji normalitas dan homogenitas dua varians dipenuhi, maka alternatif selanjutnya menguji kesamaan dua rata-rata yaitu dengan menggunakan uji-t. Hal ini dilakukan dengan tujuan untuk mengetahui ada tidaknya perbedaan penguasaan materi bangun ruang sisi datar siswa antara yang menggunakan model 
pembelajaran kooperatif Team Asissted Indovidualization dengan Direct Instruction. Adapun hipotesis statistik yang diajukan adalah sebagai berikut:

Ho : $\mu_{1} \leq \mu_{2}$

На : $\mu_{1}>\mu_{2}$

Tabel 7. Hasil Perhitungan Uji Kesamaan Dua Rata-Rata

\begin{tabular}{cccccc}
\hline Kelas & Rata-rata & Varians & $\boldsymbol{S}_{\text {gab }}$ & $t_{\text {obs }}$ & $t_{\text {kritis }}$ \\
\hline Eksperimen I & 29,857 & 12,129 & 13,55 & 6,066 & 0,032 \\
Eksperimen II & 23,045 & 14,903 & & & \\
\hline
\end{tabular}

Dengan taraf signifikan $\alpha=0,05$ dan derajat kebebasan $(\mathrm{dk})=43$ diperoleh $t_{\text {obs }}=$

6,06 dan $t_{\text {kritis }}=0,032$ dari data tersebut, dapat disimpulkan bahwa $t_{\text {obs }}>t_{\text {kritis }}$. Karena $t_{\text {obs }}>t_{\text {kritis }}$, maka $\mathrm{H}_{0}$ ditolak, artinya kemampuan pemecahan masalah matematis siswa yang menggunakan model pembelajaran kooperatif Team Asissted Individualization lebih baik dari Direct Instruction.

\section{Interpretasi Hasil Penelitian}

Setelah diterapkan model pembelajaran Team Asissted Individualization pada kelas eksperimen I dan model pembelajaran Direct Instruction pada kelas eksperimen II, terlihat bahwa kemampuan pemecahan masalah matematis kedua kelompok tersebut berbeda. Hal ini terlihat dari hasil penelitian dan pengolahan data hasil tes akhir kemampuan pemecahan masalah matematis siswa kelas eksperimen I yaitu kelas yang pembelajarannya menggunakan model Team Asissted Individualization diperoleh rata-rata 29,857, sedangkan pada kelas eksperimen II yaitu kelas yang pembelajarannya menggunakan model Direct Instruction diperoleh rata-rata 23,045. Karena kedua datanya berdistribusi normal dan kedua varians dari kelas eksperimen I dan kelas eksperimen II homogen, maka pengujian hipotesis dilakukan dengan menggunakan uji-t. Hasil uji- $t$ dari data tes akhir kelas eksperimen I dan kelas eksperimen II diperoleh nilai $\mathrm{t}_{\mathrm{obs}}=6,06$ dan $\mathrm{t}_{\mathrm{kritis}}=0,032$. Hal ini menunjukkan $t_{\text {obs }}>t_{\text {kritis }}$. Berdasarkan kriteria pengujian hipotesis maka $\mathrm{H}_{0}$ ditolak artinya kemampuan pemecahan masalah matematis siswa yang menggunakan model pembelajaran Team Asissted Individualization lebih baik dari kemampuan pemecahan masalah matematis siswa yang menggunakan model pembelajaran Direct Instruction. 
Perbandingan Kemampuan Pemecahan Masalah Matematis Siswa Antara Pembelajaran yang Menggunakan Model Team Assisted Individualization dengan Model Direct Instruction

Berdasarkan kajian teori dan hasil penelitian pada populasi kelas VIII MTs Al Wasliyah Kecamatan Anjatan dengan sampel kelas VIII B dan kelas VIII D diperoleh hasil yang saling mendukung. Sehinggan dapat disimpulkan bahwa kemampuan pemecahan masalah matematis siswa yang menggunakan model pembelajaran Team Asissted Individualization lebih baik dari yang menggunakan model pembelajaran Direct Instruction.

Kebanyakan siswa menganggap bahwa pelajaran matematika itu sulit bahkan "menakutkan". Hal ini diduga karena cara guru dalam menyampaikan materi masih belum bisa dipahami oleh siswa, serta model pembelajaran yang digunakan masih belum memberikan kesempatan kepada siswa untuk terlibat aktif dalam pembelajaran, sehingga kesan tersebut mengakibatkan siswa menjadi malas untuk memecahkan masalah matematis. Keberhasilan siswa dalam memecahkan masalah tergantung pada kemampuan yang dimiliki seorang guru dalam menyajikan materi dan model pembelajaran yang digunakan oleh guru pada proses belajar mengajar. Salah satu aspek atau kemampuan siswa dalam belajar matematika haruslah bisa memecahkan suatu masalah, adapun cara mengukur kemampuan pemecahan matematis siswa dapat dilakukan dengan soal uraian untuk diselesaikan secara tuntas dan penilaian yang dilakukan secara komperhensif (Wulandari, 2017).

Pembelajaran matematika hendaknya lebih bervariasi baik metode maupun strateginya guna mengoptimalkan potensi siswa. Karena itu pemilihan metode, strategi, dan pendekatan dalam mendesain model pembelajaran guna tercapainya iklim pembelajaran yang aktif dan bermakna adalah tuntutan yang harus dipenuhi. Matematika pada jenjang pendidikan dasar mempunyai peranan yang sangat penting sebab jenjang ini merupakan pondasi yang sangat menentukan dalam membentuk sikap, kecerdasan, dan kepribadian anak. Pelajaran matematika yang diberikan terutama pada jenjang pendidikan dasar dan menengah dimaksudkan agar pada akhir setiap tahap pendidikan, peserta didik memiliki kemampuan tertentu bagi kehidupan selanjutnya.

Model pembelajaran Direct Instruction merupakan model mengajar yang dirancang khusus untuk menunjang proses belajar yang berkaitan dengan pengetahuan deklaratif dan pengetahuan prosedural yang terstruktur dengan baik yang dapat diajarkan dengan pola kegiatan bertahap (selangkah demi selangkah). Model Direct Instruction ini dapat membantu siswa dalam meningkatkan kemampuan pemecahan masalah matematisnya, tetapi siswa menjadi pasif dalam pembelajaran atau tidak ada interaksi 
antara siswa dengan guru. Selain itu kemampuan siswa bergantung kepada kemampuan refleksi gurunya dalam proses pembelajaran.

Model pembelajaran Team Assisted Individualization, dimana guru membentuk kelompok yang heterogen dan siswa yang pandai dapat membantu siswa yang lemah, setiap peserta didik secara individual belajar materi pembelajaran yang sudah dipersiapkan oleh guru. Hasil belajar individu dibawa ke kelompok untuk didiskusikan dan saling dibahas oleh anggota kelompok dan setiap kelompok yang perolehan nilainya tinggi akan diberikan reward.

Sedangkan, kelebihan model pembelajaran Team Assisted Individualization yang di kemukakan oleh Fathurrohman (2015) menunjukkan bahwa model pembelajaran Team Asissted Individualization memungkinkan siswa lebih aktif dalam proses pembelajaran, selain itu dalam proses pembelajaran dengan menggunakan model pembelajaran Team Asissted Individualization siswa yang memiliki kemampuan lebih rendah akan terbantu dengan siswa yang memiliki kemampuan lebih tinggi karena setiap kelompok yang di bentuk dalam model pembelajaran ini bersifat heterogen. Hal ini akan mempermudah proses pembelajaran teruatama bagi siswa memiliki kemampuan yang lebih rendah karena akan di bantu teman satu kelompok nya apabila mengalami kesulitan dalam menyelesaikan soal berbentuk pemecahan masalah.

Berdasarkan kajian teori dan hasil penelitian pada populasi kelas VIII MTs Al Wasliyah Kecamatan Anjatan dengan sampel kelas VIII B dan kelas VIII D diperoleh hasil yang saling mendukung. Namun dalam penelitian ini, dapat disimpulkan bahwa kemampuan pemecahan masalah matematis siswa pada materi sistem persamaan linier dua variabel kelas VIII antara yang menggunakan model pembelajaran Team Asissted Individualization lebih baik dari yang menggunakan model pembelajaran Direct Instruction.

\section{KESIMPULAN}

Berdasarkan data penelitian tersebut, dideskripsikan sebagai berikut.

1. Kemampuan pemecahan masalah matematis siswa pada materi sistem persamaan linier dua variabel kelas VIII yang menggunakan model pembelajaran Team Asissted Individualization memiliki skor tertinggi sebesar 37, skor terendah sebesar 24, dan rata-rata sebesar 29,853 dari skor maksimum ideal 40 dengan standar deviasi sebesar 3,483 . 
Perbandingan Kemampuan Pemecahan Masalah Matematis Siswa Antara Pembelajaran yang Menggunakan Model Team Assisted Individualization dengan Model Direct Instruction

2. Kemampuan pemecahan masalah matematis siswa pada materi sistem persamaan linier dua variabel kelas VIII yang menggunakan model pembelajaran Direct Instruction memiliki skor tertinggi sebesar 31, skor terendah sebesar 17, dan rata-rata sebesar 23, 045 dari skor tertinggi ideal 40 dengan standar deviasi sebesar 3,860.

3. Berdasarkan hasil penelitian kemampuan pemecahan masalah matematis siswa pada materi sistem persamaan linier dua variabel kelas VIII yang menggunakan model pembelajaran Team Asissted Individualization lebih baik dari pada kemampuan pemecahan masalah matematis siswa pada materi sistem persamaan linier dua variabel kelas VIII yang menggunakan model pembelajaran Direct Instruction.

Hasil penelitian telah menunjukkan bahwa kemampuan pemecahan masalah matematis siswapada materi sistem persamaan linier dua variabel kelas VIII antara siswa yang pembelajarannya menggunakan model pembelajaran Team Asissted Individualization lebih baik daripada siswa yang pembelajarannya menggunakan model pembelajaran Direct Instruction.

\section{UCAPAN TERIMAKASIH}

Terimakasih disampaikan kepada semua pihak, penelitian ini dapat terwujud atas dukungan dan bantuan para ahli dan/atau pakar pendidikan yang buah pikirnya dikutip dan juga kepada Kepala MTs Al Wasliyah Kecamatan Anjatan Kabupaten Indramayu Provinsi Jawa Barat yang telah memberikan ijin serta memfasilitasi dalam pelaksanaan penelitian ini.

\section{DAFTAR PUSTAKA}

Daryanto. (2013). Inovasi Pembelajaran Efektif. Bandung: Yrama Widya.

Effendi, L. A. (2012). Pembelajaran Matematika Dengan Metode Penemuan Terbimbing Untuk Meningkatkan Kemampuan Representasi Dan Pemecahan Masalah Matematis Siswa Smp. Jurnal Penelitian Pendidikan, 13(2), 1-10. https://doi.org/10.1029/GM168.

Fathurrohman, M. (2015). Model-Model Pembelajaran Inovatif: Alternatif Desain Pembelajaran yang Menyenangkan. Yogyakarta: Ar-Ruzz Media.

Hartini, S. (2017). Pengaruh Model Pembelajaran Quantum Teaching Pada Bentuk Penilaian Portofolio Berbasis Kelas Dan Jenis Sekolah Terhadap Kemampuan Pemecahan Masalah Matematika Siswa. Volume 2, Nomor 2, Agustus 2017. Hal. 119-132. http://mathline.unwir.ac.id/index.php/Mathline/article/view/40/34

Hidayat, W \& Sariningsih, R.(2018). Kemampuan Pemecahan Masalah Matematis Dan Adversity Quotient Siswa SMP Melalui Pembelajaran Open Ended. Jurnal JNPM (Jurnal Nasional Pendidikan Matematika) Vol 2, Nomor 1 (2018) hal. 109-118 http://jurnal.unswagati.ac.id/index.php/JNPM/article/view/1027/683 
Lestari, I., Andinny, Y. \& Mailizar, M. (2019). Pengaruh Model Pembelajaran Situation Based Learning dan Kemandirian Belajar Terhadap Kemampuan Pemecahan Masalah Matematis. Jurnal JNPM (Jurnal Nasional Pendidikan Matematika) Volume 3, No. 1, Maret 2019. Hal 95-108 DOI: http://dx.doi.org/10.33603/jnpm.v3i1.1748 http://jurnal.unswagati.ac.id/index.php/JNPM/article/view/1748/1317

Lestari, K. E. \& Yudhanegara, M. R. (2015). Penelitian Pendidikan Matematika. Bandung: Refika Aditama.

Sari, D. E., dkk. (2013). Penggunaan Model Direct Instruction Sebagai Upaya Peningkatan Pemahaman Siswa Melalui Kertas Kerja. Jurnal Pendidikan UNS Volume 2 Nomor 1 halaman 11-25.

Setiani, A. (2016). Pembelajaran Matematika dengan Pendekatan Problem Based Learning untuk Mengurangi Kecemasan Matematika dan Meningkatkan Kemampuan Pemecahan Masalah Matematis Siswa MTs. Mathline: Jurnal Matematika dan Pendidikan Matematika, Vol.1, No.2, Hal 135-148. http://mathline.unwir.ac.id/index.php/Mathline/article/view/25/21.

Slameto. (2010). Belajar dan Faktor-Faktor yang Mempengaruhinya. Jakarta: Rineka Cipta.

Sugiyono. 2015. Metode Penelitian Pendidikan Pendekatan Kuantitatif, Kualitatif, dan $R \& D$. Bandung: Alfabeta

Suprijono, A. (2015). Cooperative Learning Teori \& Aplikasi PAIKEM. Yogyakarta: Pustaka Pelajar.

Sutawidjaja, A. \& Dahlan, J. A., (2011). Pembelajaran Matematika. Jakarta : Universitas Terbuka.

Trisnawati, R. (2018). Studi komparatif tentang peningkatan kemampuan pemecahan masalah matematis siswa MTs yang memperoleh pembelajaran dengan pendekatan Problem Posing dan Direct Instruction. Volume 3 Nomor 2 Agustus 2018. Hal. 101114. http://mathline.unwir.ac.id/index.php/Mathline/article/view/55/54

Undang-undang Republik Indonesia Nomor 20 Tahun 2003 tentang Sistem Pendidikan Nasional.

Wena, M. (2011). Strategi Pembelajaran Inovatif Kontemporer. Jakarta: PT Bumi Aksara. Wijaya, A. (2012). Pendidikan Matematika Realistik. Yogyakarta: Graha Ilmu.

Wulandari, S. (2017). Perbandingan kemampuan pemecahan masalah matematis siswa antara yang belajar menggunakan pembelajaran problem based learning dan problem posing.. Jurnal Formatif Volume 7 Nomor 1. Hal. 75-82 https://journal.lppmunindra.ac.id/index.php/Formatif/article/view/1291/1455. 